Article

\title{
Comparison of Soil Bacterial Communities from Juvenile Maize Plants of a Long-Term Monoculture and a Natural Grassland
}

\author{
Gergely Ujvári ${ }^{1}$, Andrea K. Borsodi ${ }^{1, *}$, Melinda Megyes ${ }^{1}\left(\right.$, Márton Mucsi ${ }^{1,2}{ }^{\circledR}$,

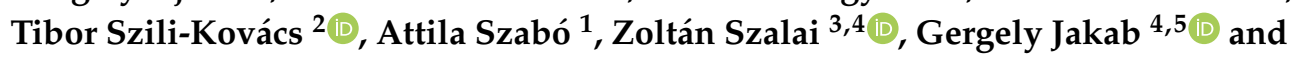 \\ Károly Márialigeti ${ }^{1}$
}

1 Department of Microbiology, ELTE Eötvös Loránd University, 1117 Budapest, Hungary; gergely.ujvari@phd.unipi.it (G.U.); mmelinda@caesar.elte.hu (M.M.); mucsi.marton@agrar.mta.hu (M.M.); attilaszabo@ttk.elte.hu (A.S.); marialigeti.karoly@ttk.elte.hu (K.M.)

2 Institute for Soil Sciences and Agricultural Chemistry, Centre for Agricultural Research, 1022 Budapest, Hungary; szili-kovacs.tibor@agrar.mta.hu

3 Department of Environmental and Landscape Geography, ELTE Eötvös Loránd University, 1117 Budapest, Hungary; szalai.zoltan@csfk.mta.hu

4 Geographical Institute, Research Centre for Astronomy and Earth Sciences, 1112 Budapest, Hungary; jakab.gergely@csfk.mta.hu

5 Institute of Geography and Geoinformatics, University of Miskolc, 3515 Miskolc, Hungary

* Correspondence: borsodi.andrea@ttk.elte.hu

Received: 3 February 2020; Accepted: 27 February 2020; Published: 2 March 2020

\begin{abstract}
Nowadays, one of the most important challenges is to ensure sustainable agricultural management of crops such as maize (Zea mays L.). Long-term crop production, however, may influence the soil properties, the composition and activity of microbial communities. The aim of this study was to compare the catabolic activity and taxonomic diversity of bacterial communities inhabiting the soil of a non-fertilized maize monoculture and a natural grassland. Samples were taken from the horizons $\mathrm{A}$ and $\mathrm{C}$ in the first part of the vegetation period. MicroResp ${ }^{\mathrm{TM}}$ technique was used to explore the catabolic potential of microbial communities and next generation amplicon sequencing to reveal the bacterial diversity. Based on the catabolic activity results, higher differences were revealed among the soil horizons than the different land uses. The highest degree carbon source utilization was detected in the soil horizon A of the natural grassland. The taxonomic composition of bacterial communities was dominated by Proteobacteria. The relative abundance of other dominant phyla (Acidobacteria, Bacteroidetes, Verrucomicrobia, Actinobacteria, Planctomycetes, Gemmatimonadetes, Chloroflexi and Patescibacteria) varied according to both the land use and soil depth. Amplicon sequences belonging to genera of r-strategist "copiotrophic" and K-strategist "oligotrophic" bacteria were identified from the soils of both maize monoculture and grassland.
\end{abstract}

Keywords: maize monoculture; grassland; soil bacteria; MicroResp; 16S rRNA gene amplicon sequencing

\section{Introduction}

Maize (Zea mays L.) is one of the most important crops around the world, not only as human food and animal feed but also as the raw material for bioethanol production. The intensive agricultural practices (as large-scale maize cultivation), however, can degrade soil ecosystems and cause a long-term decrease in soil fertility [1,2]. It is also known that factors related to agricultural management (fertilization, crop rotation, etc.) can affect the biomass, diversity and enzyme activity of soil microbiota [3,4]. 
Microorganisms have essential roles in soils by formation of soil structure, decomposition and transformation of various organic compounds as well as elimination of toxic compounds. In addition, rhizosphere microbes colonizing plant roots and surrounding soils can accumulate certain compounds, facilitate the nutrient uptake of plants, accelerate plant growth by direct or indirect ways and promote stress tolerance and defense processes against biotic and abiotic factors $[5,6]$.

Previous studies revealed that diversity and relative abundance of bacterial taxa in the maize rhizosphere and bulk soils showed considerable differences $[7,8]$. The biomass and the abundance of microorganisms, together with the diversity and the enzyme activities of maize-associated microbial communities can be influenced by the types of fertilization regimes [9-14], crop rotation [15,16] and growth stages of the maize plants $[17,18]$. Previously, Fierer et al. [19] studied the effect of different soil nitrogen concentrations on the phylogenetic diversity of bacteria in grassland and crop rotation soils using $16 \mathrm{~S}$ rRNA gene amplicon sequencing, functional diversity by shotgun metagenome sequencing and catabolic activity profiles. Their results showed differences both in phylogenetic and functional diversity and even in catabolic activity profiles along the nitrogen gradients; however, there were no strong differences in bacterial community structures, but an increase in the proportion of copiotrophic Proteobacteria and Bacteriodetes and a decrease in oligotrophic Acidobacteria was shown. From an ecological point of view, r-strategist copiotrophic bacteria (adapted to nutrient rich environments) were found to be dominant in the early-stage maize plants and in conservation agriculture while they were replaced by K-strategist oligotrophic bacteria (present in nutrient poor environments) around senescent roots and in agricultural soils farmed with conventional practices [11,20].

The results of previous research suggest that a positive correlation can be detected between microbial diversity and soil ecological functions; moreover, a shift in microbial community structure can lead to changes in ecological functions as well. Therefore, the knowledge on the function and diversity of bacterial communities in agricultural soils is important for long-term sustainable cultivation of crops such as maize. In Hungary, several long-term field experiments of maize have been maintained, representing living field laboratories that are invaluable in research, education and consultancy. The most important experiments include monocultures vs. crop rotations, comparative fertilization experiments, organic and mineral fertilizer interaction experiments, NPK dose-experiments and polyfactorial experiments [21]. However, exploration of soil microbiota from these long-term experiments just recently started in detail [22-24]. The impact of long-term agricultural practices on the structural and functional diversity of soil microbial communities is most pronounced in comparison with natural habitats. In addition, little is known about to what depths of soils the effects can be detected in agricultural crops versus natural ecosystems.

Therefore, the aim of this study was to get insight and compare the catabolic activity and taxonomic composition of bacterial communities from the different soil horizons of a non-fertilized maize monoculture and a nature conservation grassland.

\section{Materials and Methods}

\subsection{Study Sites and Sampling}

The studied maize monoculture experimental field situated near the town of Martonvásár (47.331177 N; $18.789910 \mathrm{E}$ ) in Hungary has been under the same agricultural management for almost 60 years [21,24]. A nearby "Natura 2000" grassland (47.469602 N; $18.656065 \mathrm{E})$, which was a cattle pasture until the 1990s, was used for comparison. Nowadays, the area is protected. It is dominated by Festuca rupicola and Brachypodium pinnatum (more than 35\% of the total plant coverage) and characterized by a diverse dicotyledonous flora.

Samples were taken from the soil horizons A $(0-10 \mathrm{~cm})$ and C $(40-60 \mathrm{~cm})$ using a surface sterilized Pürckhauer ground auger in spring 2017. At the time of sampling, maize plants were at the five-leaf phenological growth stage. At both sampling sites (M, Maize and G, Grassland) and soil horizons (A and C), triplicate samples (ca. $100 \mathrm{~cm}^{3}$ ) were randomly taken. On the spot, composite soil samples 
were formed from three individual subsamples of approximately the same volumes. The samples, kept in a cooler at $4-8{ }^{\circ} \mathrm{C}$, were transported to the laboratory within $3 \mathrm{~h}$ following the sampling.

Following the aseptic removal of non-decayed plant residues and thorough mixing, soil samples were divided into three parts. One was used for physical and chemical characterization, the second was sieved through a 2-mm mesh for MicroResp ${ }^{\mathrm{TM}}$ measurements and the third was processed immediately for DNA extraction.

\subsection{Physical and Chemical Analysis of the Soil Samples}

Samples for particle sizing were treated with $0.5 \mathrm{M}$ sodium pyrophosphate $\left(\mathrm{Na}_{4} \mathrm{P}_{2} \mathrm{O}_{7}\right)$ and subjected to $15 \mathrm{~min}$ of ultrasonic agitation for disaggregation $[25,26]$. Particle size distributions were measured using a Fritch Analysette 22 Microtech Plus laser diffraction particle sizer (Fritsch GmbH, Idar-Oberstein, Germany) in the range of 0.2-2000 $\mu \mathrm{m}$. Soil samples for all the other measurements were dried at $45^{\circ} \mathrm{C}$ in a drying oven until the air-dried state. The soil organic carbon (SOC) content was measured using dry combustion at $900{ }^{\circ} \mathrm{C}$ [27] using a Shimadzu TOC-L with an SSM 5000A solid sample combustion unit (Shimadzu Corp., Tokyo, Japan). The total bounded nitrogen (TN) content was measured using dry combustion at $860^{\circ} \mathrm{C}$ [27] using a Teledyne Tekmar A9000N chemiluminescent analyzer (Teledyne Technologies Incorp., Thousand Oaks, California, USA) with a Rosemount type 183 boat sampling module (Rosemount Inc. Shakopee, Minnesota, USA). $\mathrm{CaCO}_{3}$ content was determined by a Scheibler type calcimeter. Both $\mathrm{pHs}$ in distilled water and in $\mathrm{KCl}$ solution were determined at a soil:solution ratio of 1:5 (weight:volume) according to the Wageningen procedure [28].

\subsection{MicroResp ${ }^{\mathrm{TM}}$ Substrate induced Catabolic Activity Measurements}

The MicroResp ${ }^{\mathrm{TM}}$ system (Macaulay Scientific Consulting Ltd., Aberdeen, UK) was designed to quantify the microbial activity of soils [29]. The procedure was performed in accordance with the instructions of the manufacturer. In total, 23 different substrates were tested in the deep-well plates: L-(+)-arabinose $(80 \mathrm{~g} / \mathrm{L}), \mathrm{D}-(+)$-xylose $(80 \mathrm{~g} / \mathrm{L})$, D-galactose $(80 \mathrm{~g} / \mathrm{L}), \mathrm{D}$-glucose $(80 \mathrm{~g} / \mathrm{L})$, D-(-)-fructose (80 g/L), L-(-)-rhamnose $(80 \mathrm{~g} / \mathrm{L})$, mannose $(80 \mathrm{~g} / \mathrm{L})$, trehalose $(80 \mathrm{~g} / \mathrm{L})$, inositol $(80 \mathrm{~g} / \mathrm{L})$, myo- D-mannitol (80 g/L), D-(+)- D-sorbitol (80 g/L), DL-malate (40 g/L), succinate (40 g/L), citrate monohydrate $(40 \mathrm{~g} / \mathrm{L}), \mathrm{K}$ salt of gluconate $(40 \mathrm{~g} / \mathrm{L})$, L- 3,4-dihydroxy-benzoate $(12 \mathrm{~g} / \mathrm{L})$, L-alanine $(40 \mathrm{~g} / \mathrm{L})$, L-serine $(20 \mathrm{~g} / \mathrm{L})$, L-asparagine-monohydrate $(20 \mathrm{~g} / \mathrm{L})$, L-glutamine $(20 \mathrm{~g} / \mathrm{L})$, glutamate $(12 \mathrm{~g} / \mathrm{L})$, L-lysine-monohydrochloride (40 g/L) and L-arginine (12 g/L) [30]. Distilled water served as a control substrate. After $5 \mathrm{~h}$ of incubation on $25^{\circ} \mathrm{C}$, indicator color changes were photometrically detected in an Anthos 2010 photometer (Biochrom Ltd., Cambridge, UK) at $570 \mathrm{~nm}$ [31].

\subsection{Bacterial Diversity Analysis by Next-Generation DNA Sequencing}

Community DNA was isolated from $0.5 \mathrm{~g}$ of soil sample using an MO BIO power soil DNA isolation kit (MO BIO Laboratories Inc., Carlsbad, USA), according to the instructions of the manufacturer.

For PCR (polymerase chain reaction), B341F (B341F: CCT ACG GGA GGC AGC AG) and 805R (805R: GGA CTA CHV GGG TWT CTA AT) primers were used [32] with appropriate adapter sequences (CS1-TS-B341F and CS2-TS-805R). The PCR mixture contained $0.5 \mu \mathrm{L}$ of $5 \mathrm{x}$ HF buffer (Thermo Fisher Scientific), $5.0 \mu \mathrm{L}$ of dNTP mixture $(10 \mu \mathrm{M}$, Thermo Fisher Scientific), $12.25 \mu \mathrm{L}$ of distilled water, $0.625 \mu \mathrm{L}$ of each primer $(0.66 \mu \mathrm{M}), 0.25 \mu \mathrm{L}$ of Phusion ${ }^{\circledR}$ HF polymerase $(0.5 \mathrm{U}$, Thermo Fisher Scientific) and $1.25 \mu \mathrm{L}$ of metagenomic DNA. During the amplification, the following cycles were applied: $5 \mathrm{~min}$ of initial denaturation at $98^{\circ} \mathrm{C}, 25$ cycles of denaturation at $95^{\circ} \mathrm{C}$ for $40 \mathrm{~s}$, annellation at $55^{\circ} \mathrm{C}$ for $30 \mathrm{~s}$ and elongation at $72{ }^{\circ} \mathrm{C}$ for $1 \mathrm{~min}$; then, the reaction was finished with a final elongation step at $72{ }^{\circ} \mathrm{C}$ for $10 \mathrm{~min}$, and the products were cooled to $4{ }^{\circ} \mathrm{C}$. The quality of PCR products was controlled using a model 2100 Bioanalyzer (Agilent Technologies, Santa Clara, CA, USA). 
Amplicon libraries were created by pooling equal quantities of amplicons from the triplicate soil samples. Sequencing was performed on an Illumina MiSeq platform (Illumina Inc., San Diego, USA) at the Genomics Core, Research Technology Support Facility (Michigan State University, Trowbridge, USA) using a MiSeq Reagent Kit v2 (500 cycle).

Raw sequence reads were deposited in the NCBI SRA database and are accessible through the BioProject ID PRJNA547528. Sequence reads were analyzed using mothur v1.38.1 [4] based on the MiSeq SOP (http://www.mothur.org/wiki/MiSeq_SOP downloaded at 04/04/2018) [33] with the following exceptions: "deltaq" was adjusted to 10 in the "make.contigs" command; UCHIME [34] was used for chimera detection. Singleton reads were removed from the dataset according to Kunin et al. [35]. Taxonomic assignments were made using a minimum bootstrap confidence score of $80 \%$ calculated after 1000 iterations and based on the ARB-SILVA SSU Ref NR 132 database [36]. This database was also used for the generation of operational taxonomic units (OTUs) applying a 0.15 cutoff in mothur's "dist.seqs" command and using 97\% 16S rRNA gene sequence similarity, corresponding to the prokaryotic species-level threshold [37]. The determination of richness and diversity estimators was also performed with mothur using a subsampled dataset $(n=29,117)$ for every sample.

\subsection{Statistical Analysis of the Data}

After a normality test, one-way analysis of variance (ANOVA) and Tukey's honestly significant difference (HSD) were carried out to test for any significant differences between the means of soil parameters using the R 3.1.3 "stats" package (R Foundation for Statistical Computing, Vienna, Austria). A $p$-value $<0.05$ was considered significant. The catabolic potential data were standardized to the means, and then principal component analysis (PCA), R 3.1.3 with the "rda" function from the R package "vegan" [38] was applied. The UPGMA (unweighted pair group method with arithmetic mean) cluster analysis and the Simper test of the sequencing data were performed with Past3 3.20 [39], applying the Bray-Curtis similarity index. The scatter plot was created using Plotly (Plotly Technologies Inc., Montréal, Canada; https://plot.ly).

\section{Results}

\subsection{Physical and Chemical Properties of the Soil Samples}

The parent material was quaternary loess, which determined most of the physical and chemical properties of the studied soils. The texture was loam, which provided good porosity and high potential infiltration capacity [40]. Limited leaching of the calcium carbonate resulted in slightly alkaline conditions in the topsoil. The SOC content in the natural topsoil was $1.9 \%(\mathrm{~m} / \mathrm{m})$. This amount was around $4.5 \%(\mathrm{~m} / \mathrm{m})$ of the soil organic matter $(\mathrm{SOM})$ based on the application of the van Bemellen conversion factor. The SOC content of the cultivated topsoil was less than $1 \%(\mathrm{~m} / \mathrm{m})$. The SOC and TN contents were significantly higher in the topsoil of the natural grassland than the maize monoculture, but the C:N ratios were similar probably due to the higher proportion of the fresh residuals and lack of fertilization (Table 1). 
Table 1. Physical chemical properties of the studied topsoil and parent materials.

\begin{tabular}{|c|c|c|c|c|}
\hline \multirow[b]{2}{*}{ Horizon } & \multicolumn{2}{|c|}{ Maize Monoculture } & \multicolumn{2}{|c|}{ Natural Grassland } \\
\hline & A & $\mathrm{C}$ & A & C \\
\hline Sample designations & MA_17S & MC_17S & GA_17S & GC_17S \\
\hline clay $(\%, v / v)^{1}$ & $24.9 \pm 3.3$ & $24.5 \pm 0.7$ & $20.7 \pm 1.3$ & $18.8 \pm 0.3$ \\
\hline silt $(\%, v / v)^{1}$ & $45.6 \pm 1.9$ & $44.9 \pm 0.9$ & $56.3 \pm 3.3$ & $30.7 \pm 3.1$ \\
\hline sand $(\%, \mathrm{v} / \mathrm{v})^{1}$ & $29.4 \pm 2.2$ & $30.6 \pm 1.5$ & $22.9 \pm 2.1$ & $50.5 \pm 3.4$ \\
\hline $\mathrm{pH}_{(\mathrm{dw})}{ }^{1}$ & $7.7 \pm 0.2 \mathrm{ab}$ & $8.1 \pm 0.1 \mathrm{a}$ & $7.4 \pm 0.2 \mathrm{~b}$ & $8.2 \pm 0.1 \mathrm{a}$ \\
\hline $\mathrm{pH}_{(\mathrm{KCl})}{ }^{1}$ & $7.3 \pm 0.1 b$ & $7.6 \pm 0.0 \mathrm{a}$ & $7.1 \pm 0.2 b$ & $7.6 \pm 0.0 \mathrm{a}$ \\
\hline $\mathrm{CaCO}_{3}(\%, \mathrm{~m} / \mathrm{m})^{1}$ & $2.9 \pm 2.3 \mathrm{a}$ & $19.6 \pm 1.6 \mathrm{a}$ & $9.1 \pm 0.9 \mathrm{a}$ & $15.0 \pm 1.4 \mathrm{a}$ \\
\hline $\mathrm{SOC}(\mathrm{g} / \mathrm{kg})^{1}$ & $8.3 \pm 0.3 a$ & $1.2 \pm 0.2 \mathrm{a}$ & $26.1 \pm 0.6 b$ & $6.5 \pm 0.9 \mathrm{a}$ \\
\hline $\mathrm{TN}(\mathrm{g} / \mathrm{kg})^{1}$ & $0.6 \pm 0.1 \mathrm{a}$ & $0.1 \pm 0.0 \mathrm{~b}$ & $1.4 \pm 0.3 c$ & NM \\
\hline $\mathrm{C}: \mathrm{N}^{1}$ & $18.8 \pm 4.0$ & ND & $20.7 \pm 1.3$ & ND \\
\hline
\end{tabular}

1 Values are presented as the mean \pm SE. $A=0-10 ; C=40-60 \mathrm{~cm}$; clay $=<5 \mu \mathrm{m}$ fraction; silt $=5 \mu \mathrm{m}-50 \mu \mathrm{m}$ fraction; sand $=50 \mu \mathrm{m}-2000 \mu \mathrm{m} ; \mathrm{SOC}=$ soil organic carbon; total bounded nitrogen $=\mathrm{TN}$ content; $\mathrm{NM}=$ not measured; $\mathrm{ND}=$ not determined; groups that do not share a letter are significantly different at the $95 \%$ confidence interval $(p<0.05)$.

The soil of the natural grassland was located on a slope steppe. This profile contained two (A and C) horizons. The depth of the A horizon was $35 \mathrm{~cm}$. The soil type was a haplic chernozem (loamic) according to IUSS Working Group WRB2014 [41]. The arable soil was situated on a gentle slope. The profile also contained two (A and C) horizons. The depth of A horizon was $45 \mathrm{~cm}$. The soil type could be described as a eutric regosol (loamic). The difference between soil types of the grassland and the arable land could be explained by the humus loss due to the long-term cultivation.

\subsection{Substrate Induced Catabolic Activities of Soil Microbial Communities}

The catabolic activities of microbial communities were higher in the soil horizons $\mathrm{A}$ than $\mathrm{C}$ in both studied areas (Figure 1). All measured activity values in the soil horizons A were two-three times higher in the maize monoculture (MA_17S) and up to five times higher in the natural grassland (GA_17S) compared to the control $\left(\mathrm{dH}_{2} \mathrm{O}\right)$. In the soil horizons $\mathrm{A}$, the microbial respiration of the maize monoculture samples was always lower than that of the natural grassland samples, for all examined substrates. For all substrates, microbial communities from both soil horizons C (MC_17S and GC_17S) showed slightly higher activities ( $p \leq 0.05$ for all substrates and samples) than the control substrate.

On the PCA biplot (Figure 2), a clear separation of the samples can be observed. Samples from soil horizons A and C separated from each other along PC1 (which explained more than $85 \%$ of the total variability), while maize monoculture and natural grassland samples separated from each other along PC2 (which described more than $10 \%$ of the total variability). The most preferred carbon sources of the microbial communities were fructose, glucose, trehalose, malate and succinate in the soil horizons A while it was dihydroxy-benzoate in the soil horizons $\mathrm{C}$. 


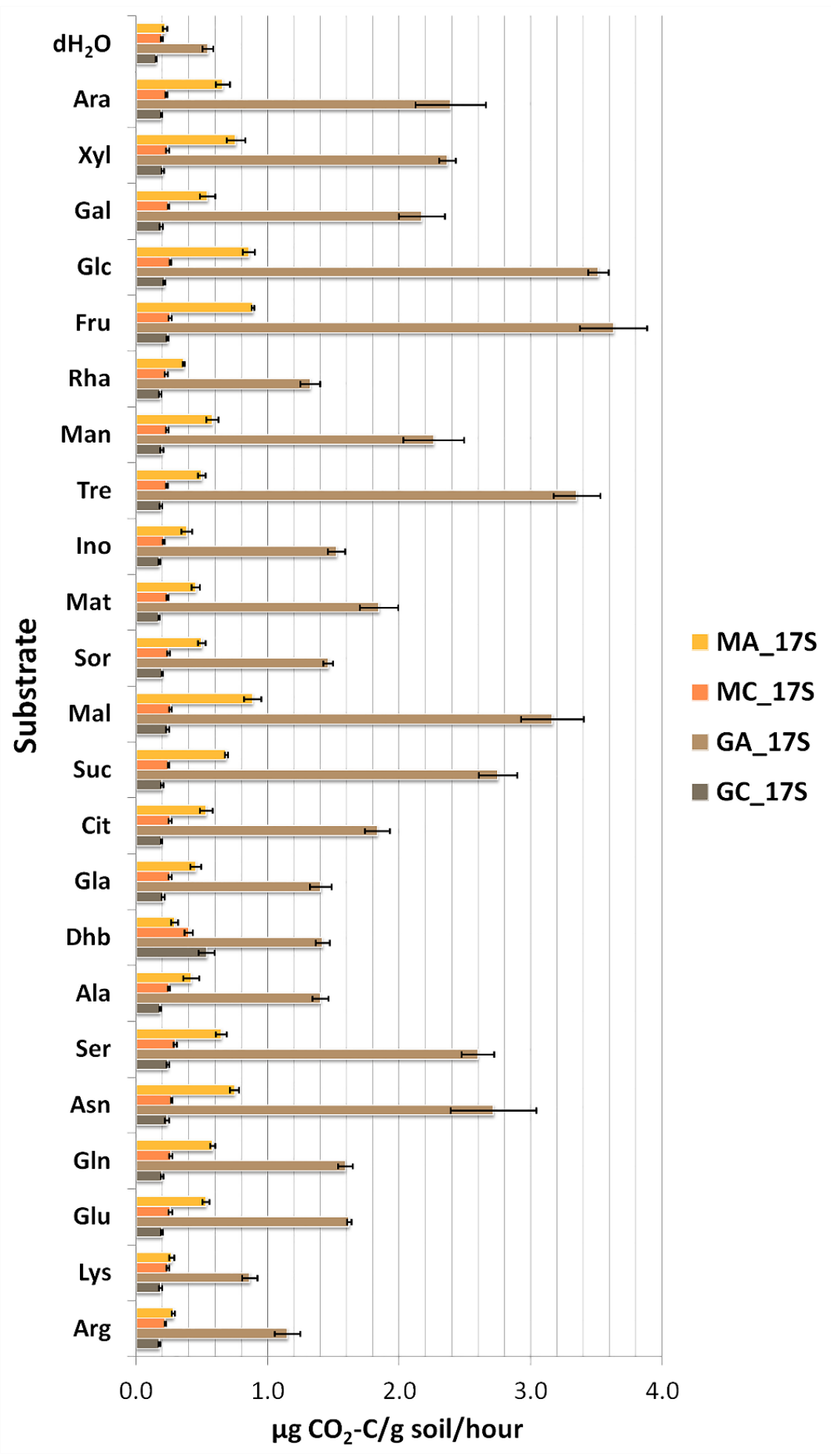

Figure 1. The metabolic potential of the maize monoculture and grassland samples measured in the MicroResp ${ }^{\mathrm{TM}}$ system with 23 substrates ( $\mu \mathrm{g} \mathrm{CO} 2-\mathrm{C} / \mathrm{g}$ soil/hour). $\mathrm{dH}_{2} \mathrm{O}$ : distilled water; Ara: arabinose; Xyl: xylose; Gal: galactose; Glc: glucose; Fru: fructose; Rha: rhamnose; Man: mannose; Tre: trehalose; Ino: inositol; Mat: mannitol; Sor: sorbitol, Mal: malate; Suc: succinate; Cit: citrate; Gla: gluconate; Dhb: dihydroxy-benzoate; Ala: alanine; Ser: serine; Asn: asparagine; Gln: glutamine; Glu: glutamate; Lys: lysine; Arg: arginine. (For sample designations see Table 1.) 


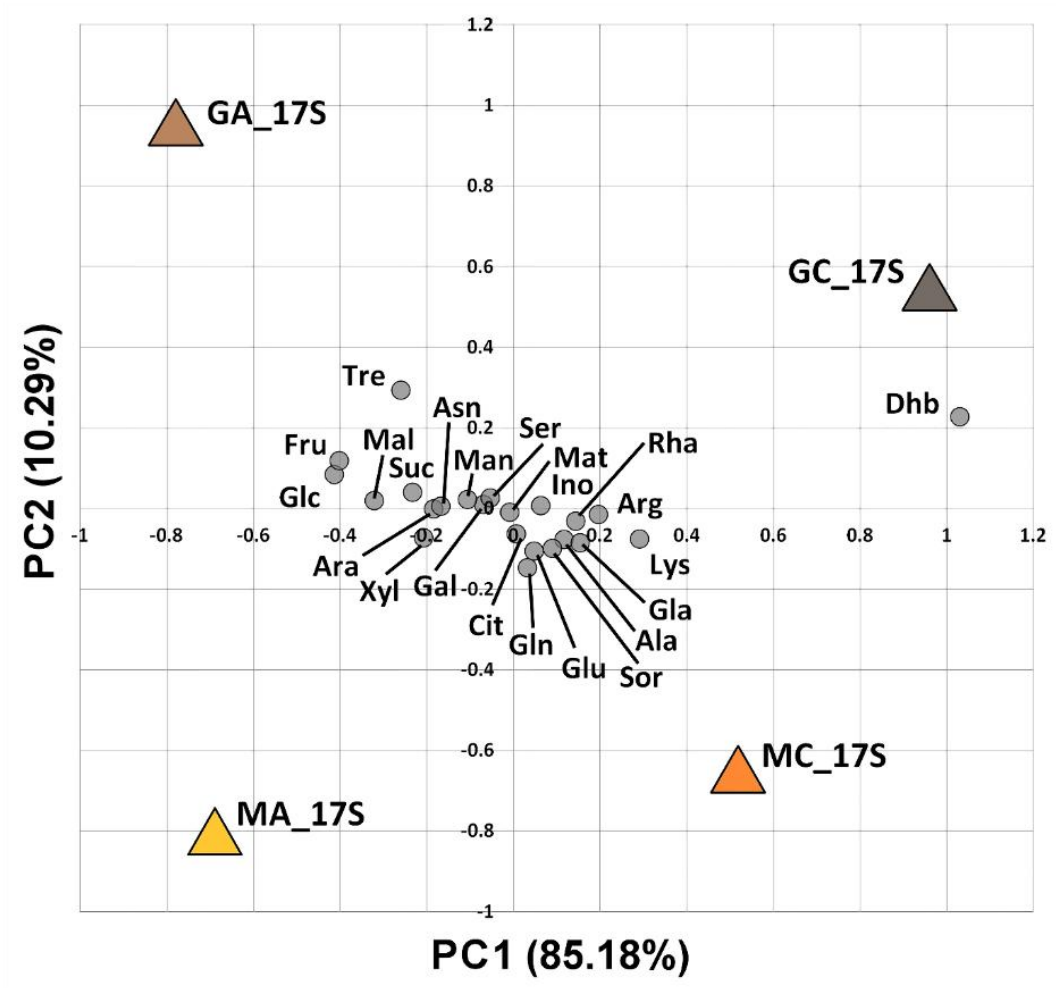

Figure 2. The PCA biplot of the maize monoculture and grassland samples as objects and organic carbon sources as variables based on the MicroResp ${ }^{\mathrm{TM}}$ data. (For substrate abbreviations see Figure 1; for sample designations see Table 1.)

\subsection{Metagenomic Diversity of Soil Bacterial Communities}

From the studied maize monoculture and natural grassland soil samples, read numbers were obtained between 29,117 and 56,488. The OTU numbers ranged from 2063 (MC_17S) to 2888 (GA_17S). Sample MA_17S had the highest diversity values among the samples. Non-parametric indices (e.g., ACE and Chao 1) and Shannon's diversity were higher in the soil horizons A than in C; however, the differences were not remarkable (Table 2).

Table 2. Changes in operational taxonomic unit (OTU) richness and diversity of the studied maize monoculture and natural grassland samples.

\begin{tabular}{ccccc}
\hline & \multicolumn{2}{c}{ Maize Monoculture } & \multicolumn{2}{c}{ Natural Grassland } \\
Horizon & A & C & A & C \\
\hline Sample sign & MA_17S & MC_17S & GA_17S & GC_17S \\
Good's coverage (\%) & 100.0 & 98.7 & 98.0 & 97.8 \\
Number of OTUs & 2803 & 2063 & 2888 & 2469 \\
Chao 1 & 2803 & 2224 & 3070 & 2828 \\
ACE & 2804 & 2304 & 3277 & 2989 \\
Inverse Simpson's (1/D) & 360 & 172 & 184 & 198 \\
Shannon's diversity (H') & 6.9 & 6.2 & 6.6 & 6.4 \\
\hline
\end{tabular}

Abbreviation: ACE, abundance-based coverage estimator.

Altogether 34 bacterial phyla and phylogenetic lineages were detected from the soil samples out of which Proteobacteria, Acidobacteria, Bacteroidetes, Verrucomicrobia, Actinobacteria, Planctomycetes, Gemmatimonadetes, Chloroflexi and Patescibacteria were present with a relative abundance higher than $1 \%$ in at least one of the samples (Figure 3). 


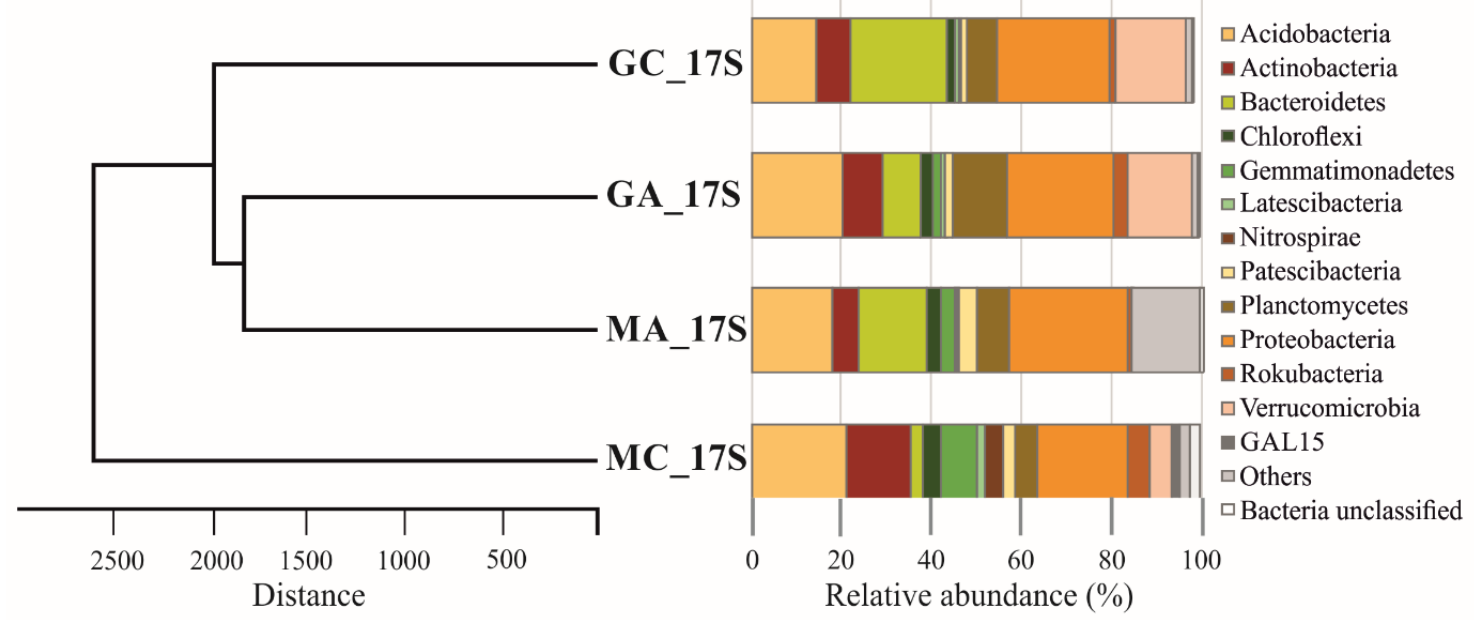

Figure 3. Relative abundance of bacterial phyla with a minimum abundance of $1 \%$ and the unweighted pair group method with arithmetic mean (UPGMA) similarity dendrogram of the maize monoculture and grassland soil samples based on the Bray-Curtis similarity index. (Sample signs are in Table 1.)

The highest relative abundance could be observed for the phyla Proteobacteria (20.2-26.5\%) and Acidobacteria (14.7-21.4\%) in almost all samples (Figure 3). The soil horizons $C$ had the highest proportion of Bacteroidetes $(21.5 \%)$ and Verrucomicrobia $(15.9 \%)$ in the natural grassland (GC_17S) while Actinobacteria (14.1\%), Gemmatimonadetes (7.7\%) and Chloroflexi (4.0\%) in the maize monoculture (MC_17S). The phyla Planctomycetes (11.8\%) and Patescibacteria (4.3\%) showed the highest proportions in the soil horizons A of natural grassland (GA_17S) and maize monoculture (MA_17S), respectively. The relative abundance was higher than $1 \%$ for the phyla Nitrospirae $(3.9 \%)$ and Latescibacteria (1.9\%) and candidate division GAL 15 (1.7\%) only in the soil horizon C of maize monoculture (MC_17S).

Based on the distribution of OTUs (operational taxonomic units), the soil horizons A were more similar to each other than soil horizons C (Figure 3). Therefore, bacterial communities from the soil horizons A of maize monoculture and natural grassland formed the closest cluster. Based on the hierarchical clustering, the soil horizon C of maize monoculture (MC_17S) was the most different sample.

The taxonomic affiliation of the 16S rRNA amplicon sequences identified at the genus level and exceeding $0.1 \%$ in at least one of the samples are presented in Figure 4 . The scatter plot shows the differences in the abundance of bacterial genera by the size of circles according to the land use and soil horizons.

The OTUs that were present in all samples and representing the highest average values were genera Gaiella (Gaiellales), Flavobacterium (Flavobacteriales), Chryseolinea (Cytophagales), Terrimonas (Chitinophagales), Pirellula (Pirellulales), Sphingomonas (Sphingomonadales), Haliangium (Myxococcales), Acidibacter and Lysobacter (Xanthomonadales), Chthoniobacter (Chthoniobacterales), Opitutus (Opitutales) and Luteolibacter (Verrucomicrobiales). In the maize monoculture, sample specific high abundance was characteristic for genera Pseudarthrobacter (Micrococcales), Ferruginibacter and Flavisolibacter (Chitinophagales), Adhaeribacter (Cytophagales), Ohtaekwangia (Cytophagales), Massilia (Betaproteobacteriales) and Arenimonas (Xanthomonadales) in the soil horizon A (MA_17S), and Nitrospira (Nitrospirales) and Dongia (Dongiales) in the soil horizon C (MC_17S). In the natural grassland soil horizon C (GC_17S), OTUs belonging to genera Paludibaculum (Solibacterales), Ferruginibacter (Chitinophagales), Parafilimonas (Chitinophagales), Ohtaekwangia (Cytophagales) and Pseudomonas (Pseudomonadales) were detected in the highest proportions.

However, it should be noted that most of the OTUs from both the maize monoculture and natural grassland resulted in unclassified or uncultured closely related sequences (data not shown), which could be identified only in higher (order or class) taxonomic levels. The Simper test (based on Bray-Curtis similarity) showed that an OTU of an uncultured Burkholderiaceae (Betaproteobacteriales) and an OUT 
of a clone lineage 0319-7L14-7L14 (0319-7L14-7L14) contributed by $1.69 \%$ and $1.45 \%$ to the variance among all samples, respectively, while some OTUs of the genera Flavobacterium (Flavobacteriales), Acidibacter (Gammaproteobacteria incertae sedis), Luteolibacter (Verrucomicrobiales), clone lineage RB41 (Pyrinomonadales), clone lineage MND1 (Betaproteobacteriales), unknown Rokubacteriales, Chthoniobacter (Chthoniobacterales), Nitrospira (Nitrospirales), uncultured Chitinophagaceae genus (Chitinophagales) and Candidatus Udaeobacter (Chthoniobacterales) contributed to the variance over $0.5 \%$ each.

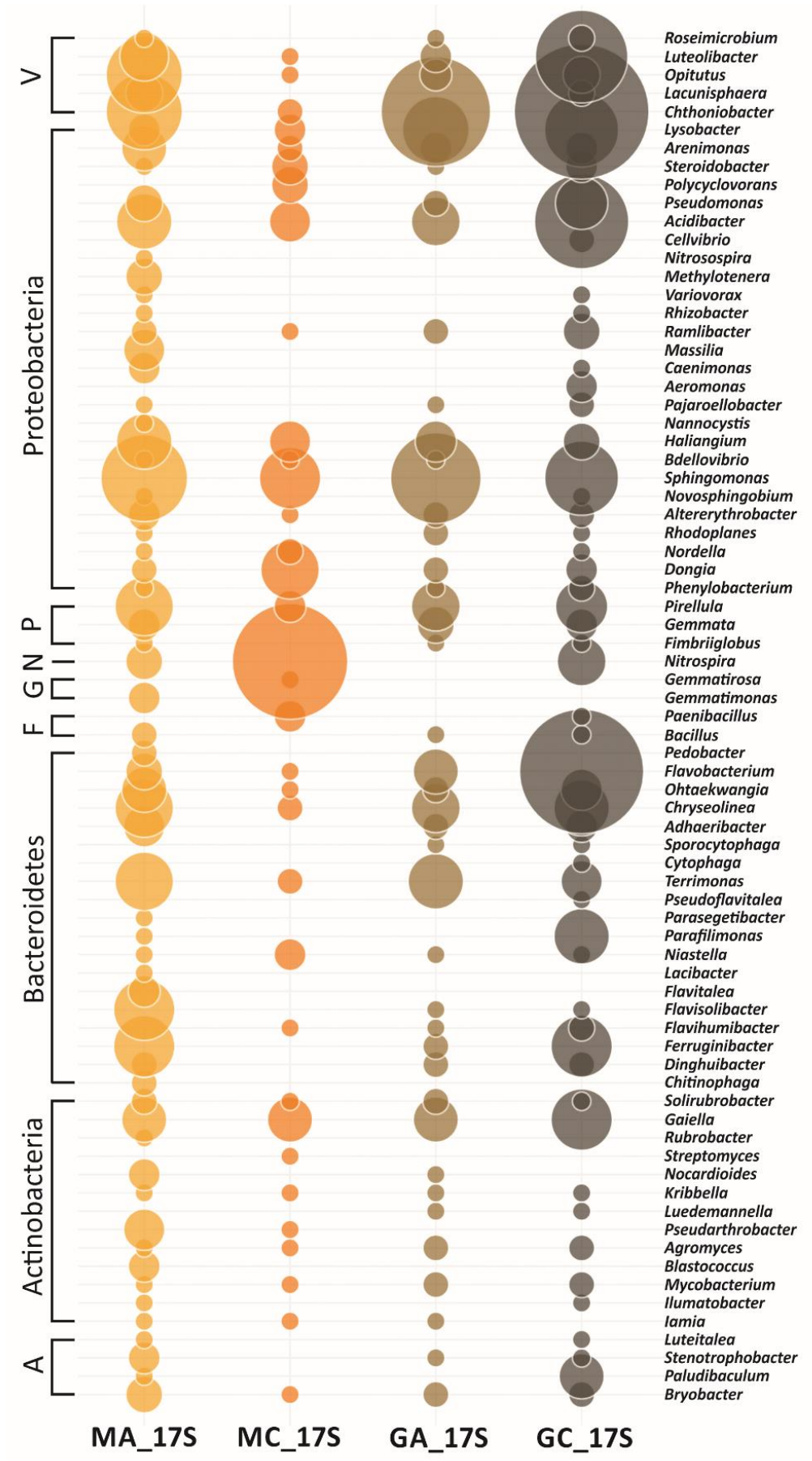

Figure 4. Distribution of $16 \mathrm{~S}$ rRNA gene amplicon sequences (relative abundance $>0.1 \%$ ) among the identified genera in the maize monoculture and grassland samples. (Abbreviations: A, Acidobacteria; F, Firmicutes; G, Gemmatimonadetes; N, Nitrospirae; P, Planctomycetes; V, Verrucomicrobia) (For sample designations see Table 1.) 


\section{Discussion}

Maize cultivation in monoculture may have a significant impact on soil structure and microbial communities in both the surface and deep horizons, which can be best detected and interpreted by comparative studies with natural ecosystems. In the present study, therefore, community level physiological profiling and next generation sequencing methods were applied to reveal and compare the metabolic potential and bacterial community structure of soil horizons $A$ and $C$ in juvenile maize plants of a long-term non-fertilized monoculture and a natural grassland.

Based on the results obtained by catabolic activity profiling of soil microorganisms, clear separations could be observed according to both the soil horizon and the land use. The results of previous studies confirmed that MicroResp ${ }^{\mathrm{TM}}$ is a suitable biological indicator method for comparing the metabolic capacity of soil microbial communities with different land managements and soil properties $[9,42,43]$.

Compared to the soil horizons $\mathrm{C}$, the measured catabolic activities were several times higher in the soil horizons A for both studied vegetation types (Figure 1), where the higher root density and organic matter content can provide more available substrates for microbes than in soil horizon C. Microbial activities of soil horizons A were extremely high in the case of monosaccharides (e.g., glucose, fructose), disaccharides (e.g., trehalose) and carboxylic acids (e.g., malate, succinate), which is not surprising, considering that these substrates are easily metabolized by microorganisms. Besides this, after standardizing to the mean activity of each sample, these substrates were shown by PCA (Figure 2) to be relatively better utilized by samples from the horizons A. One explanation to this may be that many of these substrates were previously described as root exudates or as other plant originated organic materials [44]. The separation of soil horizons $C$ was mainly due to the high utilization of a plant metabolite, namely the 3,4-dihydroxy-benzoate (a phenolic compound) as sole carbon source (Figure 2) [45]. Previously, soil depth was also found to affect microbial activities in loam soils planted with maize [46] and soils of different planted forests [47].

In the soil horizon A of the natural grassland, significantly higher total organic carbon content and the highest microbial catabolic activities were measured compared to the other samples (Table 1). It suggests that microorganisms present in the almost entirely vegetation covered topsoil horizon of natural grassland could be highly activated by easily metabolizable organic carbon sources (e.g., simple sugars, amino acids and organic acids) that are common among the exudates of different plants. The research of Turrini et al. [48] also demonstrated that respiration rates of soils with permanent plant coverage can be constantly higher than those of tilled soils. However, the fact that maize plants were in the juvenile vegetative growth stage at the time of the study should not be overlooked. Li et al. [18] found that activities of different soil microbial enzymes showed positive correlations with crop growth stages of maize. In another study, developmental stage dependent bacterial metabolic potentials were detected in the maize rhizosphere environment, based on Biolog ${ }^{\circledR}$ substrate utilization profiles [17]. The long-term monoculture in the studied maize field might also contribute to the presumably less diverse composition of plant residues and root exudates. All these factors together could have resulted in lower levels of metabolic potential in the maize monoculture. The finding that higher substrate induced microbial respiratory activities were measured in the grassland soil is consistent with results of previous studies $[9,42,49]$.

Previous research indicated less diverse microbiota in agricultural than in grassland soils, mainly due to the different plant species composition $[20,50]$. In the long-term unfertilized maize monoculture and the natural grassland soil, however, similar taxonomic diversity was found at the phylum level (Figure 3). Additionally, Buckley and Schmidt [51] revealed similar microbial community structures among plots that shared a long-term history of agricultural management despite the differences in plant community composition.

All studied samples were predominated by Proteobacteria, which was in accordance with the findings of other studies [7,15,16,24,52-55]. In addition, the dominant presence of both the so-called "copiotrophic" phyla (Actinobacteria, Bacteroidetes) and "oligotrophic" phyla (Acidobacteria, Verrucomicrobia) was detected, as classified by Fierer et al. [56]. Previously, the r-strategist "copiotrophic" 
bacteria were described primarily from the rhizosphere of maize and K-strategist "oligotrophic" bacteria from the bulk-soil samples $[8,10,52,54]$. A similar distribution of dominant bacterial phyla (such as Proteobacteria, Acidobacteria, Actinobacteria, Bacteroidetes, Planctomycetes, Gemmatimonadetes and Chloroflexi) was also found in rhizosphere soils of Bt-maize [12], in milpa maize roots and bulk soils [53] and in long-term no-tillage and conventional tillage maize soils [14] by next generation amplicon sequencing.

The relative abundance of dominant phyla containing bacteria adapted to different organic carbon concentrations showed relatively high variations according to land use and soil depth. For example, the proportion of phylum Verrucomicrobia was several times higher in both the horizons $\mathrm{A}$ and $\mathrm{C}$ of the grassland than in the maize monoculture (Figure 3). The pre-agricultural tallgrass prairie soils in the USA were also dominated by phylotypes of Verrucomicrobia, and their abundance showed positive correlation with genes of carbohydrate metabolism but negatively correlated with genes associated with nitrogen metabolism [57].

Many bacterial genera identified in this study (Figure 4), e.g., Acidibacter, Arenimonas, Dongia, Haliangium, Lysobacter, Massilia, Pseudomonas and Sphingomonas (Proteobacteria), Chryseolinea, Flavobacterium, Ohtaekwangia and Terrimonas (Bacteroidetes), Gaiella, Pseudarthrobacter and Rubrobacter (Actinobacteria), Nitrospira (Nitrospirae) and Opitutus (Verrucomicrobia), have also been revealed recently from maize rhizosphere soils of various agricultural regimes and growth stages $[8,14,16,52,55,58]$.

These bacteria can participate in the aerobic or anaerobic biodegradation of easily decomposable "fresh" and highly resistant "old" organic matter as r-strategist (e.g., Flavobacterium) and K-strategist (e.g., Opitutus), respectively. In addition, the bacteria of the maize monoculture and grassland soils may play diverse roles in the nitrogen transformations and phosphorous mobilization, as well. Genus Sphingomonas was abundant in all our samples (Figure 4) and predominated the rhizosphere soils of Bt-maize [12]. Members of the genera Sphingomonas and Flavobacterium are known as endophytic bacteria of maize $[16,59,60]$, which are capable of effective nitrogen-fixation $[60,61]$. According to both the land use and soil depth, the genus of nitrite-oxidizing Nitrospira showed the highest difference among the relative abundance values (Figure 4). Shifts of Nitrospira-like nitrifiers were also observed by Attard et al. [62] in response to different tillage practices. Other bacteria (e.g., Pseudomonas, Lysobacter, Streptomyces spp.) can have positive effects on maize as plant growth-promoting rhizobacteria [63].

However, the fact that many abundant phylotypes could not be identified in the absence of cultivated species is not to be overlooked. Therefore, the potential roles of these bacteria in the maize monoculture and the grassland soils still remain hidden.

\section{Conclusions}

The results of this study revealed that both the catabolic activity potentials and bacterial community structures differed according to the land use and soil depth. The microbial respiration was higher in the topsoils than in the subsoils, in favor of the natural grassland compared to the maize monoculture, indicating better adaptation of microorganisms in the undisturbed soils under diverse vegetation. The type of vegetation and soil depth influenced the abundance of dominant taxa more than the composition of bacterial communities both at phylum and genus levels. The identified taxa belonged to both the $\mathrm{r}$ - and $\mathrm{K}$-selected microbiota referring to diverse roles of bacteria in the studied soils.

Author Contributions: Conceptualization, A.K.B. and K.M.; Methodology, G.U., M.M. (Melinda Megyes), M.M. (Márton Mucsi), Z.S. and G.J.; data analysis, G.U., M.M. (Melinda Megyes), M.M. (Márton Mucsi) and A.S.; writing-original draft preparation, G.U. and A.K.B.; writing—review and editing, A.K.B. and K.M.; visualization, G.U. and A.K.B.; supervision and project administration, K.M. and T.S.-K. All authors have read and agreed to the published version of the manuscript.

Funding: Support was provided from the National Research, Development and Innovation Fund of Hungary, financed under the GINOP-2.3.2-15-2016-00056 funding scheme.

Acknowledgments: The authors thank T. Árendás (Agricultural Institute, Centre for Agricultural Research, Hungarian Academy of Sciences) for his excellent field organizing work and assistance in samplings. 
Conflicts of Interest: The authors declare that there is no conflict of interest.

\section{References}

1. Diacono, M.; Montemurro, F. Long-term effects of organic amendments on soil fertility. In Sustainable Agriculture Volume 2; Lichtfouse, E., Hamelin, M., Navarrete, M., Debaeke, P., Eds.; Springer: Dordrecht, The Netherlands, 2011; Volume 30, pp. 761-786.

2. Gouda, S.; Kerry, R.G.; Das, G.; Paramithiotis, S.; Shin, H.-S.; Patra, J.K. Revitalization of plant growth promoting rhizobacteria for sustainable development in agriculture. Microbiol. Res. 2018, 206, 131-140. [CrossRef] [PubMed]

3. Bandick, A.K.; Dick, R.P. Field management effects on soil enzyme activities. Soil Biol. Biochem. 1999, 31, 1471-1479. [CrossRef]

4. Schloss, P.D.; Westcott, S.L.; Ryabin, T.; Hall, J.R.; Hartmann, M.; Hollister, E.B.; Lesniewski, R.A.; Oakley, B.B.; Parks, D.H.; Robinson, C.J.; et al. Introducing mothur: Open-source, platform-independent, community-supported software for describing and comparing microbial communities. Appl. Environ. Microbiol. 2009, 75, 7537-7541. [CrossRef] [PubMed]

5. Hayat, R.; Ali, S.; Amara, U.; Khalid, R.; Ahmed, I. Soil beneficial bacteria and their role in plant growth promotion: A review. Ann. Microbiol. 2010, 60, 579-598. [CrossRef]

6. Pérez-Jaramillo, J.E.; Mendes, R.; Raaijmakers, J.M. Impact of plant domestication on rhizosphere microbiome assembly and functions. Plant Mol. Biol. 2016, 90, 635-644. [CrossRef] [PubMed]

7. Peiffer, J.A.; Spor, A.; Koren, O.; Jin, Z.; Tringe, S.G.; Dangl, J.L.; Buckler, E.S.; Ley, R.E. Diversity and heritability of the maize rhizosphere microbiome under field conditions. Proc. Natl. Acad. Sci. USA 2013, 110, 6548-6553. [CrossRef]

8. Visioli, G.; Sanangelantoni, A.M.; Vamerali, T.; Dal Cortivo, C.; Blandino, M. 16S rDNA profiling to reveal the influence of seed-applied biostimulants on the rhizosphere of young maize plants. Molecules 2018, 23, 1461. [CrossRef]

9. Sradnick, A.; Murugan, R.; Oltmanns, M.; Raupp, J.; Joergensen, R.G. Changes in functional diversity of the soil microbial community in a heterogeneous sandy soil after long-term fertilization with cattle manure and mineral fertilizer. Appl. Soil Ecol. 2013, 63, 23-28. [CrossRef]

10. Chen, L.; Zhang, J.; Zhao, B.; Zhou, G.; Ruan, L. Bacterial community structure in maize stubble-amended soils with different moisture levels estimated by bar-coded pyrosequencing. Appl. Soil Ecol. 2015, 86, 62-70. [CrossRef]

11. Ramirez-Villanueva, D.A.; Bello-López, J.M.; Navarro-Noya, Y.E.; Luna-Guido, M.; Verhulst, N.; Govaerts, B.; Dendooven, L. Bacterial community structure in maize residue amended soil with contrasting management practices. Appl. Soil Ecol. 2015, 90, 49-59. [CrossRef]

12. van Wyk, D.A.B.; Adeleke, R.; Rhode, O.H.J.; Bezuidenhout, C.C.; Mienie, C. Ecological guild and enzyme activities of rhizosphere soil microbial communities associated with Bt-maize cultivation under field conditions in North West Province of South Africa. J. Basic Microbiol. 2017, 57, 781-792. [CrossRef] [PubMed]

13. Tao, J.; Liu, X.; Liang, Y.; Niu, J.; Xiao, Y.; Gu, Y.; Ma, L.; Meng, D.; Zhang, Y.; Huang, W.; et al. Maize growth responses to soil microbes and soil properties after fertilization with different green manures. Appl. Microbiol. Biotechnol. 2017, 101, 1289-1299. [CrossRef] [PubMed]

14. Wang, H.; Li, X.; Li, X.; Wang, J.; Li, X.; Guo, Q.; Yu, Z.; Yang, T.; Zhang, H. Long-term no-tillage and different residue amounts alter soil microbial community composition and increase the risk of maize root rot in northeast China. Soil Tillage Res. 2020, 196, 104452. [CrossRef]

15. Chelius, M.K.; Triplett, E.W. The Diversity of Archaea and Bacteria in association with the roots of Zea mays L. Microb. Ecol. 2001, 41, 252-263. [CrossRef] [PubMed]

16. Correa-Galeote, D.; Bedmar, E.J.; Arone, G.J. Maize endophytic bacterial diversity as affected by soil cultivation history. Front. Microbiol. 2018, 9, 484. [CrossRef] [PubMed]

17. Baudoin, E.; Benizri, E.; Guckert, A. Impact of growth stage on the bacterial community structure along maize roots, as determined by metabolic and genetic fingerprinting. Appl. Soil Ecol. 2002, 19, 135-145. [CrossRef]

18. Li, C.H.; Ma, B.L.; Zhang, T.Q. Soil bulk density effects on soil microbial populations and enzyme activities during the growth of maize (Zea mays L.) planted in large pots under field exposure. Can. J. Soil Sci. 2002, 82, 147-154. [CrossRef] 
19. Fierer, N.; Lauber, C.L.; Ramirez, K.S.; Zaneveld, J.; Bradford, M.A.; Knight, R. Comparative metagenomic, phylogenetic and physiological analyses of soil microbial communities across nitrogen gradients. ISME J. 2012, 6, 1007-1017. [CrossRef]

20. Garbeva, P.; van Veen, J.A.; van Elsas, J.D. Microbial diversity in soil: Selection of microbial populations by plant and soil type and implications for disease suppressiveness. Annu. Rev. Phytopathol. 2004, 42, $243-270$. [CrossRef]

21. Berzsenyi, Z. Significance of the 50-year-old long-term experiments in Martonvásár in improving crop production. Acta Agron. Hungarica 2010, 58, 23-34. [CrossRef]

22. Csitári, G.; Hoffmann, S. Comparative study on soil biological parameters at a long-term field experiment. Arch. Agron. Soil. Sci. 2005, 51, 563-569. [CrossRef]

23. Magurno, F.; Sasvári, Z.; Barchi, L.; Posta, K. From monoculture to Norfolk system: How the number of crops in rotation can influence the biodiversity of arbuscular mycorrhiza assemblages in the soil. Open J. Ecol. 2014, 4, 1080-1088. [CrossRef]

24. Mayer, Z.; Sasvári, Z.; Szentpéteri, V.; Pethőné Rétháti, B.; Vajna, B.; Posta, K. Effect of long-term cropping systems on the diversity of the soil bacterial communities. Agronomy 2019, 9, 878. [CrossRef]

25. Centeri, C.; Jakab, G.; Szabo, S.; Farsang, A.; Barta, K.; Szalai, Z.; Biro, Z. Comparison of particle-size analyzing laboratory methods. Environ. Eng. Manag. J. 2015, 14, 1125-1135. [CrossRef]

26. Rieder, Á.; Madarász, B.; Szabó, J.; Zacháry, D.; Vancsik, A.; Ringer, M.; Szalai, Z.; Jakab, G. Soil organic matter alteration velocity due to land-use change: A case study under conservation agriculture. Sustainability 2018, 10, 943. [CrossRef]

27. Jakab, G.; Filep, T.; Király, C.; Madarász, B.; Zacháry, D.; Ringer, M.; Vancsik, A.; Gáspár, L.; Szalai, Z. Differences in mineral phase associated soil organic matter composition due to varying tillage intensity. Agronomy 2019, 9, 700. [CrossRef]

28. Buurman, P.; van Lagen, B.; Velthorst, E.J. (Eds.) Manual for Soil and Water Analysis; Backhuys Publishers: Leiden, The Netherlands, 1996; ISBN 9789073348585.

29. Campbell, C.D.; Chapman, S.J.; Cameron, C.M.; Davidson, M.S.; Potts, J.M. A Rapid microtiter plate method to measure carbon dioxide evolved from carbon substrate amendments so as to determine the physiological profiles of soil microbial communities by using whole soil. Appl. Environ. Microbiol. 2003, 69, 3593-3599. [CrossRef]

30. Mucsi, M.; Csontos, P.; Borsodi, A.; Krett, G.; Gazdag, O.; Szili-Kovács, T. Use of the microrespiration method to analyse the metabolic activity patterns in the soil of four characteristic sodic plant associations. Agrokémia és Talajt. 2017, 66, 165-179. [CrossRef]

31. Szili-Kovács, T.; Bárány, Á.; Füzy, A.; Takács, T.; Krett, G.; Kovács, R.; Borsodi, A. Analysis of the microbial metabolic activity patterns and mycorrhizal fungal colonisation in the rhizosphere of three soils neighbouring sodic lakes. Agrokémia és Talajt. 2017, 66, 149-164. [CrossRef]

32. Herlemann, D.P.; Labrenz, M.; Jürgens, K.; Bertilsson, S.; Waniek, J.J.; Andersson, A.F. Transitions in bacterial communities along the $2000 \mathrm{~km}$ salinity gradient of the Baltic Sea. ISME J. 2011, 5, 1571-1579. [CrossRef]

33. Kozich, J.J.; Westcott, S.L.; Baxter, N.T.; Highlander, S.K.; Schloss, P.D. Development of a dual-index sequencing strategy and curation pipeline for analyzing amplicon sequence data on the MiSeq Illumina sequencing platform. Appl. Environ. Microbiol. 2013, 79, 5112-5120. [CrossRef] [PubMed]

34. Edgar, R.C.; Haas, B.J.; Clemente, J.C.; Quince, C.; Knight, R. UCHIME improves sensitivity and speed of chimera detection. Bioinformatics 2011, 27, 2194-2200. [CrossRef] [PubMed]

35. Kunin, V.; Engelbrektson, A.; Ochman, H.; Hugenholtz, P. Wrinkles in the rare biosphere: Pyrosequencing errors can lead to artificial inflation of diversity estimates. Environ. Microbiol. 2010, 12, 118-123. [CrossRef] [PubMed]

36. Quast, C.; Pruesse, E.; Yilmaz, P.; Gerken, J.; Schweer, T.; Yarza, P.; Peplies, J.; Glöckner, F.O. The SILVA ribosomal RNA gene database project: Improved data processing and web-based tools. Nucleic Acids Res. 2012, 41, D590-D596. [CrossRef] [PubMed]

37. Busse, H.-J.; Tindall, B.J.; Ludwig, W.; Rosselló-Móra, R.; Kämpfer, P. Notes on the characterization of prokaryote strains for taxonomic purposes. Int. J. Syst. Evol. Microbiol. 2010, 60, 249-266.

38. Oksanen, J.; Blanchet, F.G.; Friendly, M.; Kindt, R.; Legendre, P.; McGlinn, D.; Minchin, P.R.; O’Hara, R.B.; Simpson, G.L.; Solymos, P.; et al. Package “Vegan": Community Ecology Package 2018. Available online: https://github.com/vegandevs/vegan (accessed on 1 February 2020). 
39. Hammer, Ø.; Harper, D.A.T.; Ryan, P.D. PAST: Paleontological statistics software package for education and data analysis. Palaeontol. Electron. 2001, 4, 1-9.

40. Jakab, G.; Madarász, B.; Szabó, J.; Tóth, A.; Zacháry, D.; Szalai, Z.; Kertész, Á.; Dyson, J. Infiltration and soil loss changes during the growing season under ploughing and conservation tillage. Sustainability 2017, 9 , 1726. [CrossRef]

41. Schad, P.; van Huyssten, C.; Michéli, E. International soil classification system for naming soils and creating legends for soil maps. In World Reference Base for Soil Resources; FAO: Rome, Italy, 2015; ISBN 9789251083703.

42. Creamer, R.E.; Stone, D.; Berry, P.; Kuiper, I. Measuring respiration profiles of soil microbial communities across Europe using MicroResp ${ }^{\mathrm{TM}}$ method. Appl. Soil Ecol. 2016, 97, 36-43. [CrossRef]

43. Zhang, Z.; Liang, S.; Wang, J.; Zhang, X.; Mahamood, M.; Yu, J.; Zhang, X.; Liang, A.; Liang, W. Tillage and crop succession effects on soil microbial metabolic activity and carbon utilization in a clay loam soil. Eur. J. Soil Biol. 2018, 88, 97-104. [CrossRef]

44. Kraffczyk, I.; Trolldenier, G.; Beringer, H. Soluble root exudates of maize: Influence of potassium supply and rhizosphere microorganisms. Soil Biol. Biochem. 1984, 16, 315-322. [CrossRef]

45. Yun-Choi, H.S.; Kim, J.H.; Lee, J.R. Potential inhibitors of platelet aggregation from plant sources, III. J. Nat. Prod. 1987, 50, 1059-1064. [CrossRef] [PubMed]

46. Blume, E.; Bischoff, M.; Reichert, J.M.; Moorman, T.; Konopka, A.; Turco, R.F. Surface and subsurface microbial biomass, community structure and metabolic activity as a function of soil depth and season. Appl. Soil Ecol. 2002, 20, 171-181. [CrossRef]

47. Gartzia-Bengoetxea, N.; Kandeler, E.; Martínez de Arano, I.; Arias-González, A. Soil microbial functional activity is governed by a combination of tree species composition and soil properties in temperate forests. Appl. Soil Ecol. 2016, 100, 57-64. [CrossRef]

48. Turrini, A.; Caruso, G.; Avio, L.; Gennai, C.; Palla, M.; Agnolucci, M.; Tomei, P.E.; Giovannetti, M.; Gucci, R. Protective green cover enhances soil respiration and native mycorrhizal potential compared with soil tillage in a high-density olive orchard in a long term study. Appl. Soil Ecol. 2017, 116, 70-78. [CrossRef]

49. Chaudhry, V.; Rehman, A.; Mishra, A.; Chauhan, P.S.; Nautiyal, C.S. Changes in bacterial community structure of agricultural land due to long-term organic and chemical amendments. Microb. Ecol. 2012, 64, 450-460. [CrossRef] [PubMed]

50. Steenwerth, K.L.; Jackson, L.E.; Calderon, F.J.; Scow, K.M.; Rolsotn, D.E. Response of microbial community composition and activity in agricultural and grassland soils after a simulated rainfall. Soil Biol. Biochem. 2005, 37, 2249-2262. [CrossRef]

51. Buckley, D.H.; Schmidt, T.M. The structure of microbial communities in soil and the lasting impact of cultivation. Microb. Ecol. 2001, 42, 11-21. [CrossRef]

52. Li, X.; Rui, J.; Mao, Y.; Yannarell, A.; Mackie, R. Dynamics of the bacterial community structure in the rhizosphere of a maize cultivar. Soil Biol. Biochem. 2014, 68, 392-401. [CrossRef]

53. Aguirre-von-Wobeser, E.; Rocha-Estrada, J.; Shapiro, L.R.; de la Torre, M. Enrichment of Verrucomicrobia, Actinobacteria and Burkholderiales drives selection of bacterial community from soil by maize roots in a traditional milpa agroecosystem. PLoS ONE 2018, 13, e0208852. [CrossRef]

54. Johnston-Monje, D.; Lundberg, D.S.; Lazarovits, G.; Reis, V.M.; Raizada, M.N. Bacterial populations in juvenile maize rhizospheres originate from both seed and soil. Plant Soil 2016, 405, 337-355. [CrossRef]

55. Yin, A.; Jia, Y.; Qiu, T.; Gao, M.; Cheng, S.; Wang, X.; Sun, Y. Poly- $\gamma$-glutamic acid improves the drought resistance of maize seedlings by adjusting the soil moisture and microbial community structure. Appl. Soil Ecol. 2018, 129, 128-135. [CrossRef]

56. Fierer, N.; Bradford, M.A.; Jackson, R.B. Toward an ecological classification of soil bacteria. Ecology 2007, 88, 1354-1364. [CrossRef] [PubMed]

57. Fierer, N.; Ladau, J.; Clemente, J.C.; Leff, J.W.; Owens, S.M.; Pollard, K.S.; Knight, R.; Gilbert, J.A.; McCulley, R.L. Reconstructing the microbial diversity and function of pre-agricultural tallgrass prairie soils in the United States. Science 2013, 342, 621-624. [CrossRef] [PubMed]

58. Jiao, X.-L.; Zhang, X.-S.; Lu, X.-H.; Qin, R.; Bi, Y.-M.; Gao, W.-W. Effects of maize rotation on the physicochemical properties and microbial communities of American ginseng cultivated soil. Sci. Rep. 2019, 9, 8615. [CrossRef] [PubMed]

59. Liu, Y.; Zuo, S.; Xu, L.; Zou, Y.; Song, W. Study on diversity of endophytic bacterial communities in seeds of hybrid maize and their parental lines. Arch. Microbiol. 2012, 194, 1001-1012. [CrossRef] [PubMed] 
60. Gao, J.; Lv, F.; Wang, X.; Yuan, M.; Li, J.; Wu, Q.; Sun, J. Flavobacterium endophyticum sp. nov., a nifH gene-harbouring endophytic bacterium isolated from maize root. Int. J. Syst. Evol. Microbiol. 2015, 65, 3900-3904. [CrossRef]

61. Sun, J.-G.; Zhang, Y.-C.; Xu, J.; Hu, H.-Y. Isolation, identification and inoculation effect of nitrogen-fixing bacteria Sphingomonas GD542 from maize rhizosphere. Chinese J. Eco-Agriculture 2010, 18, 89-93. [CrossRef]

62. Attard, E.; Poly, F.; Commeaux, C.; Laurent, F.; Terada, A.; Smets, B.F.; Recous, S.; Roux, X. Le Shifts between Nitrospira-and Nitrobacter-like nitrite oxidizers underlie the response of soil potential nitrite oxidation to changes in tillage practices. Environ. Microbiol. 2010, 12, 315-326. [CrossRef]

63. Philippot, L.; Raaijmakers, J.M.; Lemanceau, P.; van der Putten, W.H. Going back to the roots: The microbial ecology of the rhizosphere. Nat. Rev. Microbiol. 2013, 11, 789-799. [CrossRef]

(C) 2020 by the authors. Licensee MDPI, Basel, Switzerland. This article is an open access article distributed under the terms and conditions of the Creative Commons Attribution (CC BY) license (http://creativecommons.org/licenses/by/4.0/). 